\title{
PERMAINAN PUZZLE SEBAGAI MEDIA EDUKASI KONSUMSI SAYUR DAN BUAH DI TK/PG YASPORBI SURABAYA
}

\author{
Nadia Farhani \\ Universitas Nahdlatul Ulama Surabaya, nadiafarhani@unusa.ac.id \\ Viera Nuriza Pratiwi \\ Universitas Nahdlatul Ulama Surabaya, vieranpratiwi@ unusa.ac.id
}

\begin{abstract}
Abstrak
Konsumsi sayur dan buah merupakan salah satu syarat dalam pemenuhan gizi seimbang pada anak balita. Akan tetapi, anak balita cenderung tidak mau mengonsumsi sayur dan buah karena berbagai faktor. Pertama, sayur dan buah rasanya cenderung pahit dan tidak enak dibandingkan makanan ringan atau makanan manis. Kedua, pengetahuan mengenai pentingnya mengonsumsi sayur dan buah juga masih kurang. Oleh karena itulah, pengabdian kepada masyarakat ini dilakukan untuk meningkatkan kesadaran dan konsumsi sayur dan buah pada anak balita khususnya murid-murid TK/PG Yasporbi Surabaya. Metode pengabdian masyarakat yang dilakukan adalah metode experimental dengan edukasi menggunakan pemutaran video dan permainan puzzle. Video yang diputarkan berupa lagu anak-anak tentang sayur dan buah serta nama-nama kedua jenis makanan tersebut. Populasi yang terlibat dalam kegiatan pengabdian kepada masyarakat sebanyak 90 orang dari kelas Play Group, TK A dan TK B. Hasil kegiatan pengabdian masyarakat ini menunjukkan bahwa murid-murid TK/PG Yasporbi Surabaya sangat tertarik dan antusias menonton video lagu sayur dan buah. Selain itu, murid-murid TK berpartisipasi dalam permainan puzzle dan berani untuk menyebutkan nama-nama sayur dan buah didepan kelas. Edukasi gizi menggunakan metode permainan puzzle dapat diterapkan kepada anak balita untuk meningkatkan konsumsi sayur dan buah.
\end{abstract}

\begin{abstract}
Fruit and vegetable consumption is one of the aspects of a balanced nutrition in toddler. However, toddlers are less likely to consume fruit and vegetable because of many factors. Firstly, fruit and vegetable has a bitter taster. Besides, toddlers think that it is not as delicious as confectionary or savoury snacks. Therefore, this community development event was done in TK/PG Yasporbi Surabaya in order to improve fruit and vegetable awareness in toddler and also to increase its consumption. The method of this community development event was experiment study using educational approach. The education method employed was video and puzzle games. The population involved in this event was 90 students from varying degree of age. The results showed that the TK/PG Yasporbi Surabaya students were very enthusiast watching the video. Moreover, they participated in the puzzle game and played in fruit and vegetable name riddle game. In short, nutrition education using puzzle game approach can be applied in toddler to increase their fruit and vegetable consumption.
\end{abstract}

\section{PENDAHULUAN}

Indonesia merupakan salah satu negara penghasil sayur dan buah yang banyak jika dibandingkan dengan negara lain. Disisi lain, tingkat konsumsi sayur dan buah di Indonesia masih tergolong cukup rendah jika dibandingkan negara-negara lain. Di Indonesia, konsumsi rata-rata buah dan sayur pertahun adalah 40,06 kg dan 37,94 kg, sedangkan yang direkomendasikan FAO adalah $65,75 \mathrm{~kg}$ per tahun. Konsumsi sayur dan buah merupakan salah satu syarat dalam pemenuhan gizi seimbang. Konsumsi sayur dan buah sangat penting dilakukan sehari-hari demi tercapainya gizi 
seimbang karena sayur dan buah berfungsi sebagai zat pengatur, sumber vitamin, mineral, serat, dan antioksidan. Berbagai kajian menunjukkan bahwa manfaat dari mengkonsumsi sayur dan buah adalah mengontrol berat badan/kegemukan (obesitas), penanggulangan penyakit Diabetes, mencegah gangguan gastrointestinal, mencegah kanker kolon (usus besar), mengurangi tingkat kolesterol dan penyakit kardiovaskuler (Santoso, 2011). Konsumsi sayur dan buah yang cukup juga menurunkan risiko sulit buang air besar (BAB/sembelit) dan kegemukan (Kementrian kesehatan RI, 2014). Pentingnya konsumsi sayur dan buah tidak hanya berlaku bagi orang dewasa, tetapi juga penting bagi anakanak. Permasalahan yang sering terjadi pada anak-anak adalah rendahnya tingkat konsumsi sayur dan karena mereka cenderung tidak menyukai rasa sayur dan buah.

Konsumsi sayur dan buah pada anak berhubungan dengan tingkat pengetahuan dan motivasi dari orang tua. Karakteristik anak-anak adalah cenderung pemilih pada jenis makanan tertentu terutama rasa manis dan kurang menyukai sayur karena rasa yang dianggap tidak enak. Faktor lain yang mempengaruhi adalah kurangnya pengetahuan dan informasi tentang nilai gizi yang ada pada sayur dan buah. Faktorfaktor di atas dapat dirubah dan dibentuk dengan melakukan edukasi dan membiasakan makan sayur dan buah sejak dini. Edukasi dilakukan untuk memberikan pengetahuan pada anak-anak tentang pentingnya makan sayur dan buah. Edukasi sejak dini yang dilakukan dapat menjadi dasar untuk perubahan perilaku pada anak (Desi dkk., 2015).

Metode edukasi gizi dengan media permainan puzzle bertujuan agar anak bias lebih paham dan tidak merasa terpaksa. Permainan puzzle sebagai media edukasi merupakan metode yang menyenangkan dan mempu menghadirkan sesuatu kegembiraan dalam belajar anak dan tanpa sadar menstimulus otak. Hasil penelitian Desi dkk., (2018) yang melakukan pendidikan gizi melalui permainan wayang didapatkan hasil terdapat peningkatan signifikan pada konsumsi sayur dan buah pada anak taman kanakkanak setelah dilakukan edukasi dengan media permainan wayang. Penelitian serupa dilakukan oleh Anggraini dkk., (2014), edukasi gizi menggunakan media animasi juga berpengaruh pada pengetahuan gizi. Permainan dinilai lebih efektif digunakan pada pendidikan anak karena lebih menyenangkan, menarik, dan disukai anak.

Berdasarkan analisis situasi yang telah dilakukan, permasalahan yang ada adalah konsumsi sayur dan buah pada anak cenderung rendah karena anak-anak 
lebih suka pada makanan manis. Oleh karen itulah, pengabdian kepada masyarakat dengan tema "permainan puzzle sebagai media edukasi konsumsi sayur dan buah di tk/pg yasporbi Surabaya" ini dilakukan untuk meningkatkan konsumsi sayur dan buah pada anak balita.

\section{Gambaran Umum Masyarakat Sasaran}

TK/PG Yasporbi Surabaya merupakan lembaga pendidikan Taman Kanak-Kanak dan Playgroup (PG) atau Kelompok Bermain (KB) anak usia dini yang berada di Jalan Jemur Andayani III/3 Kelurahan Jemur Wonosari, Kecamatan Wonocolo, Kota Surabaya. TK/PG Yasporbi Surabaya terdiri dari tiga tingkatan kelas yaitu PG atau KB, TK A dan TK B yang dibagi berdasarkan kelompok usia. TK/PG Yasporbi didirikan sejak tahun 1972 oleh Ikatan Pegawai Bank Indonesia sebagai wujud kepedulian terhadap pendidikan bangsa. Aktivitas yang dapat diperoleh anak-anak di sekolah ini antara lain bercocok tanam, melukis, menari, olah vokal, teater dan kulintang serta berbagai aktivitas seru dan menarik lainnya seperti praktek kesehatan.

Praktek kesehatan yang sering dilakukan para murid di TK/PG Yasporbi adalah mencuci tangan dan menyanyikan lagu gizi seimbang. Akan tetapi, pengamalan lagu tentang gizi seimbang belum sepenuhnya dilakukan dengan baik karena konsumsi sayur dan buah masih sangat kurang. Hal ini juga sangat disayangkan oleh para guru pendidik di TK/PG Yasporbi karena usaha untuk mendorong anak muridnya mengonsumsi makanan gizi seimbang masih belum mencapai target yang diinginkan.

Oleh karena itulah, kegiatan pengabdian masyarakat mengenai edukasi konsumsi sayur dan buah di TK/PG Yasporbi perlu dilaksanakan guna meningkatkan kesadaran dan kemauan anak usia dini mengonsumsi sayur dan buah. Kegiatan pengabdian masyarakat ini dilakukan dengan menggunakan media video dan permainan puzzle untuk menambah wawasan mereka tentang konsumsi sayur dan buah.

\section{METODE}

Metode pelaksanaan dalam program pengabdian kepada masyarakat adalah pemberian edukasi konsumsi sayur dan buah menggunakan pemutaran video dan permainan puzzle kepada anak usia dini di TK/PG Yasporbi Surabaya. Video tentang konsumsi sayur dan buah dalam bentuk lagu diputarkan saat berlangsungnya kegiatan. Video terdiri dari 3 jenis lagu yang berbeda namun dengan tema sayur dan buah. Pemutaran video dilakukan dengan tujuan untuk menstimulasi otak dan fisik anak, yaitu bernyanyi dan 
menghapal isi lagu mengenai pentingnya makan sayur dan buah serta menstimulasi aktivitas fisik untuk menari mengikuti irama lagu. Pemutaran video dilakukan berulang-ulang agar pesan yang disampaikan dalam lagu tersebut dapat diingat oleh anak-anak.

Edukasi konsumsi sayur dan buah dilakukan dengan metode permainan Puzzle. Setelah pemutaran video tentang pentingnya makan sayur dan buah serta video lainnya tentang nama- nama buah dan sayur, para murid melakukan permainan puzzle tentang nama-nama buah dan sayur. Beberapa murid TK berpartisipasi dalam bermain tebak nama buah didepan murid TK lainnya. Murid TK/PG Yasporbi dibimbing oleh kakakkakak mahasiswa Prodi S1 Gizi Universitas Nahdlatul Ulama Surabaya saat bermain games.

Beberapa murid juga diikutsertakan dalam kegiatan menari saat pemutaran video. Hal ini dilakukan agar para murid melakukan aktivitas fisik dan menggerakan tubuh saat melafalkan lagu. Kegiatan menari akan menambah semangat para murid TK untuk mengaplikasikan lagu yang diputar dalam video agar mau mengonsumsi sayur dan buah. Video tersebut selanjutnya akan diputar oleh guru-guru di TK setiap pagi agar aplikasi edukasi konsumsi sayur dan buah dapat berjalan secara berkesinambungan.

\section{HASIL DAN PEMBAHASAN}

Peserta yang mengikuti kegiatan pengabdian kepada masyarakat di TK/PG Yasporbi sebanyak 90 orang yang terdiri dari PG atau KB, TK A dan TK B. Rentang usia murid TK/PG Yasporbi adalah 2.5-6 tahun. Kegiatan ini diikuti oleh seluruh murid TK/PG Yasporbi di halaman sekolah dan aula. Kegiatan edukasi mengenai konsumsi sayur dan buah dilakukan dengan cara pemutaran video lagu "ayo makan sayur dan buah" dan "nama-nama sayur dan buah". Pemutaran video dilakukan berulang kali agar para murid mengerti dan memahami isi lagu tersebut. Selain itu, setelah lagu diperdengarkan, para murid TK/PG Yasporbi diajak beraktivitas fisik yaitu menari mengikuti irama lagu. Setelah aktivitas mendengarkan lagu, menyanyi dan menari, aktivitas terakhir yaitu permainan puzzle tebak nama sayur dan buah yang diikuti oleh para murid TK/PG Yasporbi.

Metode edukasi yang pertama adalah pemutaran video dari Fun Cican yang berjudul Sayur dan Buah. Liriknya adalah sebagai berikut:

Aku suka sayur, Aku suka buah Sayurnya ijo, Buahnya segar Engga pake nangis makan sayurnya Engga pake rewel makan buahnya

Reff: Brokoli wortel tomat Semangka bayam apel jeruk Badan kuat ga gampang sakit Bikin kita semakin sehat 
Lirik lagu tersebut sangat sederhana dan dinyanyikan dengan nada yang sederhana pula. Para murid TK/PG Yasporbi mudah menghafal dan mengikuti lagu sayur dan buah dari Fun Cican tersebut. Antusias peserta kegiatan pengabdian masyarakat ini dapat dilihat dari banyaknya muridnya yang turut serta menyanyikan lagu. Video yang kedua adalah pengenalan nama-nama sayur dari video Uwa \& Friend. Nama-nama sayur disebutkan secara alfabetik dari A hingga Z. Video edukasi dapat dilihat pada Lampiran 3.

Setelah pemutaran video yang kedua, video berikutnya adalah Ayo Makan Sayur - Bernyanyi dan Bergoyang dari Baby You. Para murid TK/PG Yasporbi diajak oleh kakak- kakak dari Prodi S1 Gizi UNUSA untuk mengikuti tarian yang mereka contohkan. Beberapa murid mengikuti gerakan lagu sedangkan murid lainnya menyaksikan video dan tarian yang dilakukan. Gerakan tari mengikuti irama lagu misalnya kata "ayo makan sayur" dilengkapi gerakan tangan ke arah tubuh seperti gerakan ajakan. Hal ini dilakukan agar anak-anak khususnya murid TK/PG Yasporbi memahami makna yang terkandung dalam lirik lagu tersebut. Selain itu, gerakan memudahkan menghafal lagu dan meningkatkan aktivitas fisik.

Aktivitas terakhir yaitu permainan puzzle tebak nama sayur dan buah. Semua murid diajak untuk menyebutkan namanama buah dan sayur. Terdapat 10 jenis buah dan 10 jenis sayur yang diperkenalkan pada kegiatan pengabdian kepada masyarakat tersebut. Selanjutnya beberapa murid ditantang kedepan aula untuk berani menyebutkan nama-nama sayur dan buah. Murid yang berani dan berhasil menyebutkan nama-nama sayur dan buah mendapatkan reward berupa hadiah yang berisi makanan dan susu. Kegiatan ini menyebabkan antusias dan keberanian murid lainnya terpancing untuk berani menyebutkan nama-nama sayur dan buah karena bisa mendapatkan hadiah.

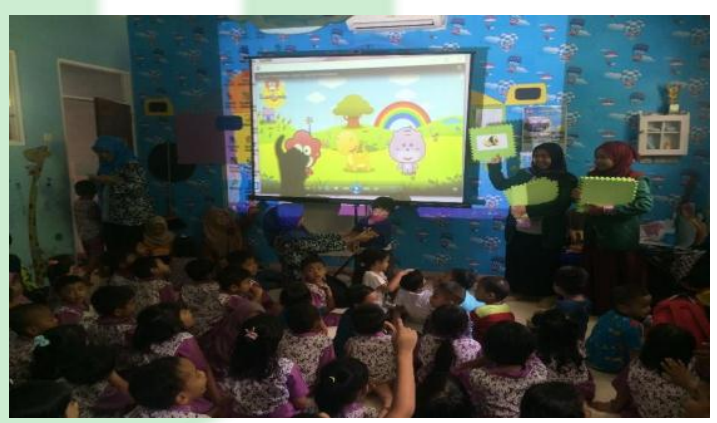

Gambar 1. Kegiatan Memperkenalkan Nama-Nama Buah dan Sayur

\section{KESIMPULAN}

Berdasarkan uraian pada hasil dan pembahasan di atas, maka dapat disimpulkan sebagai berikut.

Kegiatan penyuluhan dan edukasi konsumsi sayur dan buah dilakukan dengan cara menampilkan video lagu sayur dan buah. Kegiatan pasca edukasi dilakukan dengan permainan menebak 
nama-nama sayur dan buah dengan media permainan puzzle. Mayoritas murid TK/PG Yasporbi antusias dalam menerima materi edukasi konsumsi sayur dan buah. Rata-rata murid TK/PG Yasporbi mampu menyebutkan namanama sayur dan buah dengan benar

\section{REFERENSI}

Anggraini Enggar, Tamtomo Didik Gunawan, Hanim Diffah. (2014). Perbedaan Pengaruh Pelajaran Gizi Menggunakan Media Animasi dan Ceramah Terhadap Pengetahuan Gizi, Sikap dan Perilaku Konsumsi Buah dan Sayur Pada Anak Sekolah Dasar. Jurnal Gizi dan Kesehatan, 1(2), 169-182

Desi, Bella Mesyamtia, Martinus Ginting. 2018. Pendidikan Gizi Melalui Permainan Wayang Terhadap Peningkatan Konsumsi Sayur Dan Buah. Jurnal Vokasi Kesehatan.

Desi, Hanim D. H, \& Kusnandar. (2015). Pendidikan Gizi Melalui Permainan Model Ular Tangga Untuk Meningkatkan Kadar Hemoglobin Dan Konsumsi Protein Hewani Bagi Anak Taman Kanak-Kanak, . Jurnal Gizi dan Kesehatan, 2(2), 101-113

Kemenkes RI. 2014. Pedoman Gizi Seimbang. Jakarta.

Santoso, I. A. 2011. Serat Pangan (dietary fiber) dan manfaatnya bagi kesehatan. Magistra, 23(75), 35 